\title{
The biological function of the cellular prion protein: an update
}

\author{
Marie-Angela Wulf, Assunta Senatore and Adriano Aguzzi
}

\begin{abstract}
The misfolding of the cellular prion protein $\left(\operatorname{PrP}^{C}\right)$ causes fatal neurodegenerative diseases. Yet $\operatorname{PrP}^{C}$ is highly conserved in mammals, suggesting that it exerts beneficial functions preventing its evolutionary elimination. Ablation of $\operatorname{PrP}^{C}$ in mice results in well-defined structural and functional alterations in the peripheral nervous system. Many additional phenotypes were ascribed to the lack of $\operatorname{PrP}^{C}$, but some of these were found to arise from genetic artifacts of the underlying mouse models. Here, we revisit the proposed physiological roles of $\operatorname{PrP}^{C}$ in the central and peripheral nervous systems and highlight the need for their critical reassessment using new, rigorously controlled animal models.
\end{abstract}

The cellular prion protein $\left(\operatorname{PrP}^{C}\right)$ is a cell surface protein expressed in a variety of different organs and tissues with high expression levels in the central and peripheral nervous systems [1]. It is mainly known for its infamous role in prion diseases, where its misfolding and aggregation cause inevitably fatal neurodegenerative conditions [2]. Prion diseases are transmissible and misfolded prion protein $\left(\mathrm{PrP}^{\mathrm{Sc}}\right)$ is-according to the "protein-only hypothesis" - the only disease-causing agent [3]. Under this view, it is puzzling that a protein underlying such severe diseases is highly conserved throughout mammals [4]. This suggests the existence of distinct benefits and, potentially, important physiological functions.

A definitive, fully satisfactory understanding of the physiological function of $\operatorname{PrP}^{\mathrm{C}}$ has been lacking for a long time. Very recently, we identified a native function of $\operatorname{PrP}^{\mathrm{C}}$ in the peripheral nervous system and the underlying mechanism of that function [5]. However, $\operatorname{PrP}^{C}$ is also highly expressed in the central nervous

\footnotetext{
* Correspondence: adriano.aguzzi@usz.ch

Institute of Neuropathology, University of Zurich, Rämistrasse 100, CH-8091 Zürich, Switzerland
}

\section{The prion protein undergoes post-translational proteolytic processing}

The cellular prion protein is encoded by the Prnp gene. In mice, the entire protein-coding open-reading frame is encoded within the third exon of Prnp [6-8]. After translation and cotranslational extrusion into the lumen of the endoplasmic reticulum, $\operatorname{PrP}^{\mathrm{C}}$ adopts its physiological structure with a $\mathrm{C}$-terminal globular domain and an N-terminal flexible tail [9] (Fig. 1). The N-terminal tail consists of two charged clusters (CC1 and $\mathrm{CC} 2)$, the octarepeat region (OR) and a hydrophobic domain (HD). Additionally, two N-glycosylation sites are located in the globular domain upstream of the sialylated GPI-anchor at the C-terminus $[10,11]$.

After being transported to the cell membrane, $\operatorname{PrP}^{C}$ tosides extracellularly in lipid rafts, where it is attached the outer leaflet by a glycosyl phosphoinosityl (GPI) 12]. It undergoes rapid constitutive endocytosis [15] and caveolin pathways [16].

As part of its post-translational metabolism, $\operatorname{PrP}^{\mathrm{C}}$ can undergo proteolytic cleavage events termed, in analogy to amyloid precursor protein processing, $\alpha-, \beta$-, and possibly also $\gamma$-cleavage (Fig. 1). These cleavage events release the so-called $\mathrm{N} 1+\mathrm{C} 1, \mathrm{~N} 2+\mathrm{C} 2$, and $\mathrm{C} 3$ fragments, respectively [17-20]. These events may be important for both physiology and pathology. Alpha cleavage prevents the $\mathrm{C} 1$ fragment from being converted into $\operatorname{PrP}^{\mathrm{Sc}}[21]$, the rate of the beta cleavage is increased in the disease [19], and $\mathrm{PrP}^{\mathrm{C}}$ deletion mutants lacking the alpha-cleavage site show spontaneous neurodegeneration exhibiting pathological features distinct from those of prion diseases (reviewed in [22]). 


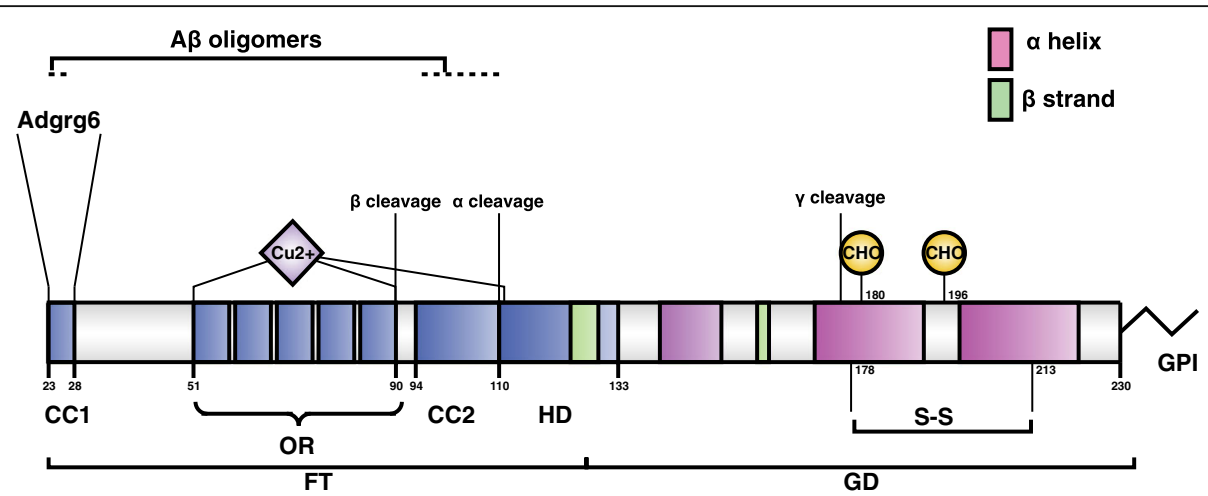

Fig. 1. Structural organization of $\operatorname{PrP}^{C}$. Schematic representation of mature mouse PrPC ${ }^{C}$, showing protein domains, sites of post-translational modification, and binding sites for divalent cations and protein interactors of functional relevance. CC1 charge cluster 1, OR octapeptide repeats, CC2 charge cluster 2, HD hydrophobic domain, FT flexible tail, GD globular domain. Structurally defined domains are depicted by pink (a-helix) and green ( $\beta$-strand) boxes. GPI glycosylphosphatidylinositol anchor, CHO glycosylation site, S-S disulfide bridge. $a, \beta$, and $\gamma$ cleavage sites are indicated. Copper binding sites $\left(\mathrm{Cu}^{2+}\right)$ within and outside the octapeptide region are reported as well as the sites involved in the interaction with $A \beta$ oligomers and with the G-protein-coupled receptor Adgrg6

The enzyme responsible for $\operatorname{PrP}^{C}$ cleavage may not be unique, and several members of the ADAM (a_disintegrin and metalloproteinase) family have been implicated [23-26]. $\mathrm{PrP}^{\mathrm{C}}$ can bind divalent cations such as copper and zinc [27] by the octarepeat-containing flexible tail and it has been reported to interact with a plethora of different proteins. These interactions have been taken to reflect its putative role in several cellular processes, but they may also simply be a consequence of the unstructured, flexible conformation of the $\mathrm{N}$-terminus of $\operatorname{PrP}^{\mathrm{C}}$.

\section{Genetic pitfalls of PrPC gene ablation}

Soon after $\mathrm{PrP}^{\mathrm{Sc}}$ was proposed to be the causative agent of prion diseases, Prnp knockout mice lacking $\operatorname{PrP}^{\mathrm{C}}$ were generated in order to answer the question whether the loss of physiological $\mathrm{PrP}^{\mathrm{C}}$ function would lead to neurodegeneration in prion diseases. The first Prnp null mouse strain, designated Prnp ${ }^{-/}$, or Zurich I (ZrchI, Prnp $\left.{ }^{\mathrm{ZH1} / \mathrm{ZH} 1}\right)$, was produced in a mixed $\mathrm{C} 57 \mathrm{BL} / 6 \mathrm{~J} \times$ $129 / \mathrm{Sv}\left(\right.$ ev) background [28] and a second line of $\operatorname{PrP}^{C_{-}}$deficient mice, known as Npu or Edinburgh (Edbg), was produced with a pure 129/Ola genetic background [29]. In a first round of characterization, these mice were not found to show any clear abnormality except for their resistance to prion infection [30]. They developed and bred normally, and although they displayed subtle alterations in behavior [28], their otherwise apparent normality seemed to rule out a physiological function of $\operatorname{PrP}^{C}$ that is essential for life. If there is one, it is highly redundant or it can be compensated for. $\operatorname{Pr} \mathrm{P}^{\mathrm{C}}$-deficient mice from which the entire Prnp gene was removed [31-34] develop progressive cerebellar ataxia, which was originally attributed to the loss of $\mathrm{PrP}^{\mathrm{C}}$ but was later discovered to be due to the deletion of a splice acceptor site in exon 3 of Prnp [35]. This led to aberrant overexpression of the $\operatorname{PrP}^{\mathrm{C}}$ paralogue gene (Prnd) encoding Doppel (Dpl) [36, 37], causing selective neurodegeneration of cerebellar Purkinje cells. Notably, the reintroduction of Prnp in mice overexpressing Prnd in the brain rescued the phenotype, suggesting a functional link between the two proteins [38].

Later, using the Cre-loxP system, conditional $\operatorname{PrP}^{C}$ knockout NFH-Cre/tg37 mice were generated to examine the effects of acute $\operatorname{PrP}^{\mathrm{C}}$ depletion on neuronal viability and function in the brain of 9-week-old adults. This approach was thought to avoid compensatory mechanisms active at the embryonal stage that would have masked $\operatorname{PrP}^{C}$ loss of function phenotypes [39]. Again, depleting neuronal $\operatorname{PrP}^{C}$ in adult mice did not result in neurodegeneration or histopathological changes, but it led to subtle electrophysiological abnormalities in the hippocampus (Table 1). A closer look at different neuronal and other cell functions in $\operatorname{PrP}^{\mathrm{C}}$-ablated mice revealed a number of differences from wild-type mice that were attributed to the physiological function of $\operatorname{PrP}^{\mathrm{C}}$. While some of these studies were consistent among different $\operatorname{PrP}^{\mathrm{C}}$-deficient lines, others yielded contradictory results depending on methodologies and the mouse models that were used (Table 2).

A genetic confounder has been shown to underlie some of these inconsistencies [40, 41]. For many years, knockout alleles were usually created in embryonic stem cells from the Sv129 strain of mice, and the resulting mice were backcrossed to C57BL/6 mice [42]. This practice typically leads to variable, poorly controlled Mendelian segregation of polymorphic alleles whose distribution depends on their genetic linkage to the knockout allele. All Prnp knockout mouse lines have been generated in this way with the exception of the "Edinburgh" mouse, which was maintained in a pure 129 background [42]. 
Table 1 Lines of PrPC-ablated mice covered in this review

\begin{tabular}{|c|c|c|c|c|}
\hline Name & Year produced & Reference & Genetic background & "Doppel artifact" \\
\hline Zurich I (Zrchl, ZH1) & 1992 & {$[28]$} & Mixed C57BL/6J x 129/Sv(ev) & No \\
\hline Edinburgh (Edbg) & 1994 & [29] & 129/Ola & No \\
\hline Nagasaki (Ngsk) & 1996 & {$[31]$} & Mixed C57BL/6J x 129/Sv(ev) & Yes \\
\hline Rcm0 & 1997 & [33] & Mixed C57BL/6J x 129/Sv(ev) & Yes \\
\hline Zurich II (Zrchll, ZH2) & 2001 & [34] & Mixed C57BL/6J x 129/Sv(ev) & Yes \\
\hline NFH-Cre/tg37 (adult onset) & 2002 & [39] & Mixed C57BL/6J x 129/Sv(ev) & No \\
\hline Zurich III (ZrchllI, ZH3) & 2016 & {$[42]$} & C57BL/6J & No \\
\hline
\end{tabular}

Bold indicates mixed genetic background of at least two distinct mouse strains, possibly leading to the "flanking-gene problem". Italic indicates mice maintained on single, pure genetic background

Table 2 Proposed physiological roles of cellular prion protein

\begin{tabular}{|c|c|c|c|}
\hline Role of $\operatorname{PrP}^{C}$ in & Phenotype of Prnp ${ }^{-/-}$model system & $\begin{array}{l}\text { Report } \\
\text { (mouse model/cell line used) }\end{array}$ & $\begin{array}{l}\text { Contradictory } \\
\text { reports }\end{array}$ \\
\hline \multirow[t]{2}{*}{$\begin{array}{l}\text { Synaptic transmission } \\
\text { and plasticity }\end{array}$} & Reduced long-term potentiation & $\begin{array}{l}\text { [58] (ZH1) } \\
\text { [29] (Edgb) }\end{array}$ & $\begin{array}{l}\text { [61] }\left(\mathrm{ZH} 1, \text { other }^{a}\right) \\
\text { [98] (ZH1) }\end{array}$ \\
\hline & Reduced excitatory and inhibitory synaptic transmission & $\begin{array}{l}\text { [58] (ZH1) } \\
{[62](\mathrm{ZH} 1, \mathrm{Ngsk})}\end{array}$ & $\begin{array}{l}\text { [61] }\left(\mathrm{ZH} 1, \text { other }^{a}\right) \\
{[147](\mathbf{Z H 1})}\end{array}$ \\
\hline \multirow[t]{2}{*}{ Memory formation } & Reduced spatial learning and memory & [64] $\left(\right.$ other $\left.^{b}\right)$ & [28] (ZH1) \\
\hline & Reduced avoidance learning and memory & $\begin{array}{l}{[65](\mathrm{ZH1})} \\
{[148](\mathbf{N g s k})}\end{array}$ & [68] $(\mathrm{ZH} 1)$ \\
\hline $\begin{array}{l}\text { Stabilization of sleep } \\
\text { and circadian rhythm }\end{array}$ & $\begin{array}{l}\text { Altered circadian rhythm, increased sleep fragmentation, } \\
\text { increased SWA after sleep deprivation }\end{array}$ & [71] (ZH1, Edgb) & [74] $\left(\right.$ Other $\left.^{b}\right)$ \\
\hline \multirow[t]{3}{*}{ Neuronal excitability } & Reduced Kv4.2 currents & [77] (ZH1, HEK293T) & \\
\hline & Reduced sAHP and calcium-activated potassium currents & $\begin{array}{l}\text { [79] (ZH1) } \\
\text { [80] (ZH1) } \\
\text { [82] (ZH1) } \\
\text { [39] (Tg35) } \\
\text { [83] (ZH1) }\end{array}$ & \\
\hline & Increased susceptibility to Kainate-induced seizures & [84] (ZH1) & [41] $\left(\right.$ Other $\left.^{b}\right)$ \\
\hline \multirow[t]{2}{*}{ Calcium homeostasis } & Reduced VGCC currents & [80] (ZH1) & [83] (ZH1) \\
\hline & Increased calcium buffering & [83] (ZH1) & \\
\hline \multirow[t]{2}{*}{$\begin{array}{l}\text { Glutamate receptor } \\
\text { function }\end{array}$} & Increased NMDA currents, nociception and depressive-like behavior & $\begin{array}{l}{[90](\mathbf{Z H} \mathbf{1})} \\
{[91,92](\mathbf{Z H 1})}\end{array}$ & \\
\hline & Upregulation of Kainate receptor subunits & [84] (ZH1) & \\
\hline \multirow[t]{2}{*}{ Neurite outgrowth } & Delayed development of cerebellar circuitry & [120] (ZH1) & \\
\hline & Reduced neurite outgrowth in vitro & [106] (ZH1) & \\
\hline $\begin{array}{l}\text { Toxicity elicited by } \\
\text { oligomeric species }\end{array}$ & Protected from LTP reduction induced by toxic A $\beta$ species & [98] (ZH1, other') & $\begin{array}{l}\text { [102] (ZH1) } \\
\text { [103] (ZH1) } \\
\left.\text { [104] } \text { (Other }^{b}\right) \\
\text { [105] }\left(\text { Other }^{a}\right)\end{array}$ \\
\hline \multirow[t]{2}{*}{ Neuroprotection } & Larger lesions in model of acute cerebral ischemia & $\begin{array}{l}\text { [122] (ZH1) } \\
{[123](\mathbf{Z H 1})} \\
{[124](\mathbf{Z H 1})}\end{array}$ & \\
\hline & Decreased SOD activity & [133] (ZH1) & [135] (ZH1) \\
\hline \multirow{3}{*}{$\begin{array}{l}\text { Copper, zinc, iron, and } \\
\text { lactate metabolism }\end{array}$} & Reduced zinc content in primary neurons & [95] (ZH1, SH-SY5Y) & \\
\hline & Increased lactate-uptake in cultured astrocytes & [96] (ZH1) & \\
\hline & Altered iron and copper metabolism & [139] $\left(\right.$ Other $\left.^{\mathrm{a}}\right)$ & \\
\hline $\begin{array}{l}\text { Peripheral myelin } \\
\text { maintenance }\end{array}$ & Age-dependent demyelinating neuropathy & $\begin{array}{l}{[141](\mathbf{Z H 1}, E d g b)} \\
{[42](Z H 3)}\end{array}$ & \\
\hline
\end{tabular}

Bold indicates mixed genetic background of at least two distinct mouse strains, possibly leading to the "flanking-gene problem". Italic indicates mice maintained on single, pure genetic background. Mouse lines specified as "other" are: ${ }^{a} \mathrm{ZH} 1$ backcrossed to FVB; ${ }^{b}$ Edgb (back-)crossed to C57BL/10; ${ }^{\mathrm{C}} \mathrm{Edbg}$ backcrossed to C57BL6 
Even after more than 12 generations of backcrossing, a small part of the chromosome around the Prnp locus still stems from the 129 strain, raising the question whether any observed phenotypes were actually due to polymorphisms in genes flanking Prnp. Indeed, we found that SIRPa, a polymorphic Prnp-flanking gene, is actually responsible for an alleged Prnp ${ }^{-/-}$phenotype: the inhibition of macrophage phagocytosis of apoptotic cells that was observed in $\operatorname{PrP}^{\mathrm{C}}$-deficient mice with mixed genetic background but not in co-isogenic Prnp ${ }^{-/-}$mice [40]. Recently, a new $\operatorname{PrP}^{C}$-deficient mouse strain, Prnp ${ }^{\mathrm{ZH} 3 / \mathrm{ZH} 3}$, was produced in our lab using TALENmediated genome editing in fertilized mouse oocytes and maintained in a pure C57BL/6 J genetic background [42]. These strictly co-isogenic C57BL/6 J-Prnp ${ }^{\mathrm{ZH} 3 / \mathrm{ZH} 3}$ mice differ from wild-type mice only by eight deleted nucleotides in the Prnp reading frame. In an effort to improve the quality of studies on the function of the cellular prion protein, we are distributing $\operatorname{Prnp}^{\mathrm{ZH} 3 / \mathrm{ZH} 3}$ mice without requesting any kind of Material Transfer Agreement, hence enabling better-controlled future studies. In view of the broad availability of Prnp ${ }^{\mathrm{ZH} 3 / \mathrm{ZH} 3}$ mice, we contend that the use of mixed-background $\operatorname{PrP}^{\mathrm{C}}$-deficient mice is obsolete and liable to artifacts.

Do further mammal species teach us more about the function of $\mathrm{PrP}^{\mathrm{C}}$ ? The gene encoding $\operatorname{PrP}^{\mathrm{C}}$ has been ablated experimentally in cattle [43] and goats [44], and a naturally occurring Prnp knockout goat has been reported [45]. While no pathological phenotypes were reported in any of these animals, it may be rewarding to perform specific investigations of these animals, e.g., concerning the integrity of the peripheral nervous system in advanced age.

A large set of human genomic data was analyzed to quantify the penetrance of variants of the human $\operatorname{PrP}^{\mathrm{C}}$ gene $(P R N P)$ in prion disease [46]. Surprisingly, heterozygous loss-of-function variants were identified in three individuals. These individuals in their $50 \mathrm{~s}$ and $70 \mathrm{~s}$ are probably healthy, and no evidence of any neurological defect or peripheral neuropathy was documented. This result suggests that heterozygous loss of PRNP in humans may not be haploinsufficient. It remains to be assessed, however, whether homozygous deletion and therefore complete loss of $\mathrm{PrP}^{\mathrm{C}}$ may create a disease in humans.

\section{Evidence for a role of synaptic $\operatorname{PrP}^{C}$ in memory and sleep}

$\mathrm{PrP}^{C}$ is strongly expressed in both neurons and glial cells of the CNS [1]. In neurons, $\operatorname{PrP}^{\mathrm{C}}$ is preferentially localized in the pre- and postsynaptic compartments of nerve terminals. Immunocytochemical studies by light and electron microscopy in primate and rodent brains [47, 48], as well as examination of an EGFP-tagged $\operatorname{PrP}^{\mathrm{C}}$ in transgenic mice, showed that $\operatorname{PrP}^{C}$ is enriched along axons and in pre-synaptic terminals $[49,50]$ and that it undergoes anterograde and retrograde axonal transport [51, 52]. $\operatorname{PrP}^{C}$ is also present in postsynaptic structures $[53,54]$. It has recently been shown that sialic acid within the GPI-anchor is important for targeting $\operatorname{PrP}^{C}$ to synapses [55]. This expression pattern implies that $\operatorname{PrP}^{\mathrm{C}}$ might be involved in preserving normal synaptic structure and function by regulating synaptic transmission and plasticity (Fig. 3). Supporting this notion, synaptic dysfunction and synaptic loss are a prominent and early event in prion diseases $[56,57]$.

Early reports showed that $\operatorname{PrP}^{\mathrm{C}}$-deficient mice (both ZH1 and Edbg) display reduced long-term potentiation (LTP) in hippocampal Schaffer collaterals and weakened inhibitory GABAergic synaptic transmission $[58,59]$. These defects have been claimed to be rescued by a human PRNP transgene [60]. However, none of these results were reproduced in $\operatorname{PrP}^{\mathrm{C}}$-deficient mice of three different genetic backgrounds (Table 2). These discrepancies have remained essentially unexplained for the past 20 years [61]. Later studies reported a $\operatorname{PrP}^{\mathrm{C}}$ dosage-dependent facilitation of synaptic transmission, with $\operatorname{PrP}^{\mathrm{C}}$-over-expressing mice exhibiting supra-physiological synaptic transmission [62]. This effect seemed to result from a more efficient recruitment of pre-synaptic fibers that, in turn, may depend on $\operatorname{PrP}^{\mathrm{C}}$ expression levels.

LTP is one of the neurophysiological correlates of synaptic plasticity, the ability of synapses to change their strength in response to previous activity. Because synaptic plasticity (LTP) in the hippocampus underlies learning and memory formation [63], any LTP deficits may result in cognitive defects. Initial reports did not show any reduction in memory performance of $\operatorname{Prnp}{ }^{\mathrm{ZH} 1 / \mathrm{ZH} 1}$ mice in the Morris Water Maze test [28]. However, a later study found deficiencies in spatial learning and memory in $\operatorname{PrP}^{\mathrm{C}}$-deficient mouse lines on various backgrounds [64]. These deficits were explained by reduced LTP in the dentate gyrus in $\operatorname{PrP}^{\mathrm{C}}$-deficient mice in vivo, and were rescued by neuronal expression of $\mathrm{PrP}^{\mathrm{C}}$. $\operatorname{Prnp}{ }^{\mathrm{ZH} 1 / \mathrm{ZH} 1}$ mice were reported to have impaired memory performance only when aged ( 9 months). Several molecular mechanisms for this defect have been proposed, but none were verified at the mechanistic level [65-67]. These results stand in contrast to another study carried out in $\operatorname{Prnp}{ }^{\mathrm{ZH} 1 / \mathrm{ZH} 1}$ mice that did not reveal any memory impairment up to an age of 2 years [68]. Thus, a role for $\operatorname{PrP}^{\mathrm{c}}$ in memory is still contentious.

A role of $\mathrm{PrP}^{\mathrm{C}}$ in sleep homeostasis and sleep continuity has also been proposed and loss of such a function for $\operatorname{PrP}^{\mathrm{C}}$ would be of clinical relevance. Indeed, it would explain the disruption of the sleep pattern that occurs as a prominent symptom in some forms of prion diseases 
like sporadic and familial fatal insomnia [69, 70]. Both Prnp ${ }^{\mathrm{ZH} 1 / \mathrm{ZH} 1}$ and co-isogenic Prnp ${ }^{\mathrm{Edbg} / \mathrm{Edbg}}$ mice were reported to display altered circadian rhythms, increased sleep fragmentation, and increased slow wave activity (SWA) following sleep deprivation [71]. The latter phenotype was rescued by reintroduction of $\mathrm{PrP}^{\mathrm{C}}$ expression [72]. It was suggested that the difference in SWA between wild-type and Prnp null mice reflected a function of $\operatorname{PrP}^{C}$ in neurotransmission or a protective role on synapses [73]. Another study confirmed sleep disturbance in Prnp knockout mice. However, using a prolonged sleep deprivation protocol, the defect was found to be associated with reduced slow-wave activity and to altered hormonal reactivity to prolonged stress [74]. Interestingly, deterioration of slow-wave activity was found to contribute to sleep deficits in Alzheimer's disease $(\mathrm{AD})$ and was reversed by enhancing $\mathrm{GABA}_{\mathrm{A}}$ ergic inhibition [75].

The molecular bases of sleep regulation are not completely understood. Tantalizingly, recent work indicates that calcium-dependent hyperpolarization is critical to sleep duration, and that sleep deterioration is associated with impairment of calcium-dependent potassium channels, voltage-gated calcium channels (VGCC), and Nmethyl-D-aspartate (NMDA) glutamate receptors [76]. Since both hyperpolarization linked to calcium dyshomeostasis and NMDA receptor-related hyperexcitability were documented in Prnp ablated mice (discussed in the next section), loss of $\mathrm{PrP}^{\mathrm{C}}$-dependent control of these ion channels may underlie the sleep disruption in $\mathrm{PrP}^{\mathrm{C}}$ deficient mice and perhaps also in prion diseases.

\section{Possible functions for PrP ${ }^{C}$ are suggested by interaction partners}

Albeit controversial, the participation of $\operatorname{PrP}^{\mathrm{C}}$ in neurobiological processes, and particularly in sleep regulation and memory, raises the question whether the cellular prion protein modulates synaptic mechanisms and neuronal excitability at a molecular level. Insights into possible mechanisms may be provided by the documented interaction of $\operatorname{PrP}^{\mathrm{C}}$ with several ion channels and metabotropic glutamate receptors (Fig. 2). However, caution is needed

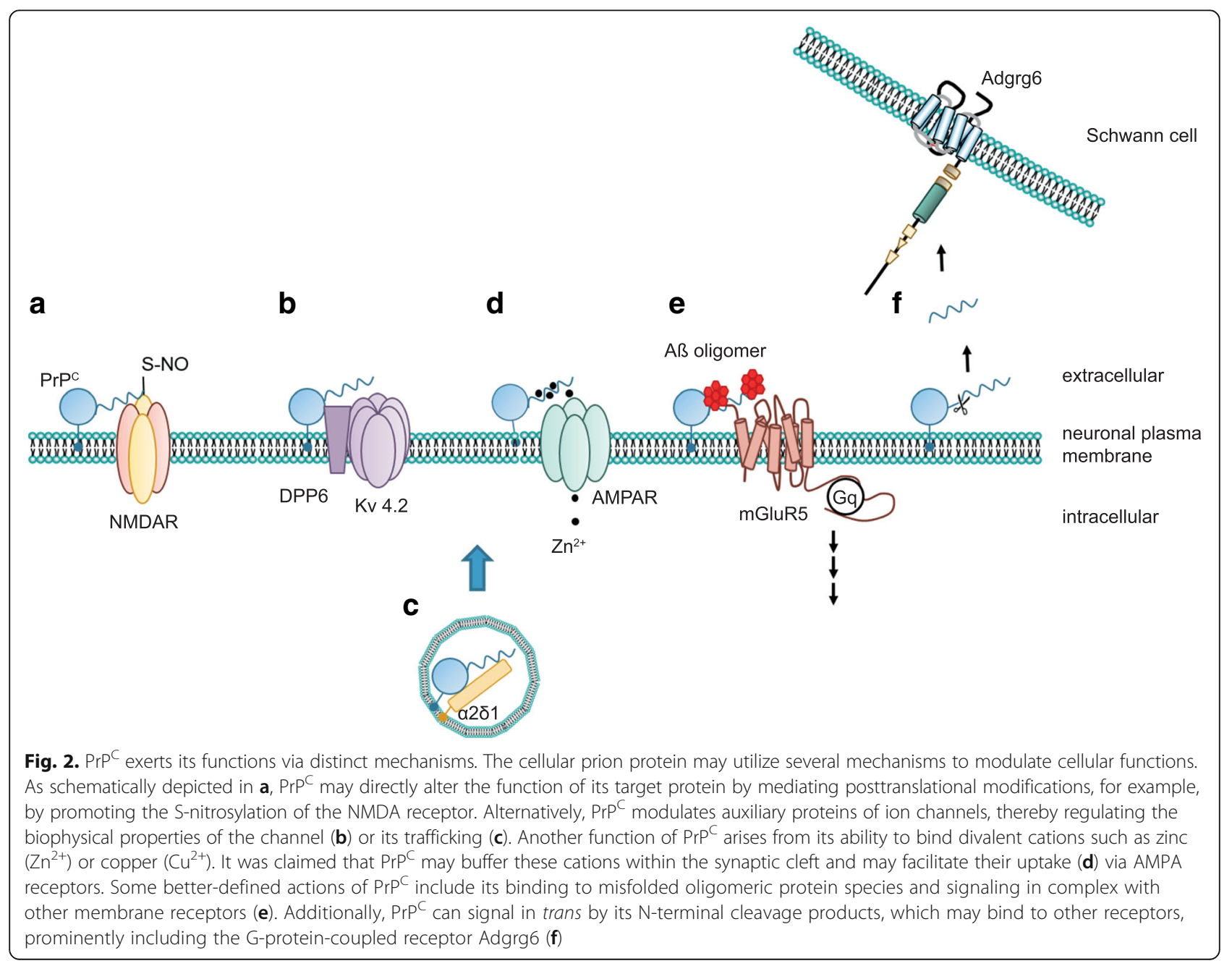


while screening the crowded $\operatorname{PrP}^{C}$ interactome: only interactions with molecular partners displaying a functional correlate to $\operatorname{PrP}^{\mathrm{C}}$ binding should be considered of potential biological relevance.

$\operatorname{PrP}^{\mathrm{C}}$ interacts with Dipeptidyl peptidase-like 6 (DPP6), an auxiliary subunit of the voltage-gated potassium channel 4.2 (Kv4.2), which leads to increased and prolonged currents through this channel, thereby reducing cellular excitability [77]. Also, $\operatorname{PrP}^{\mathrm{C}}$ and a mutant $\operatorname{PrP}^{\mathrm{C}}$ version that is linked to a genetic prion disease have been shown to co-immunoprecipitate with the auxiliary subunit $\alpha 2 \delta-1$ of VGCCs in transgenic mice [78]. Mutant $\operatorname{PrP}^{C}$ affected $\alpha 2 \delta-1$ trafficking and function at the synapses. The molecular role of $\operatorname{PrP}^{\mathrm{C}}$ in VGCC function under physiological conditions remains unclear (Fig. 3). However, deficits in VGCC currents and calcium homeostasis were reported in $\operatorname{Prnp}{ }^{\mathrm{ZH1} / \mathrm{ZH} 1}$ neurons $[79,80]$ and were proposed to underlie the reduced slow after hyperpolarization (sAHP) seen in $\operatorname{PrP}^{\mathrm{C}}$-deficient mice. The sAHP is a property of many neurons that is evoked by repetitive action potentials and controls subsequent action potential firing. The intermediate-conductance, calcium-activated potassium channel (IkCa) has been claimed to control this neurophysiological parameter [81].

Not only could the sAHP defect be reproduced by independent research groups in Prnp ${ }^{\mathrm{ZH} 1 / \mathrm{ZH} 1}$ mice [80, 82, 83], it has also been shown in an adult-onset model of $\operatorname{PrP}^{\mathrm{C}}$

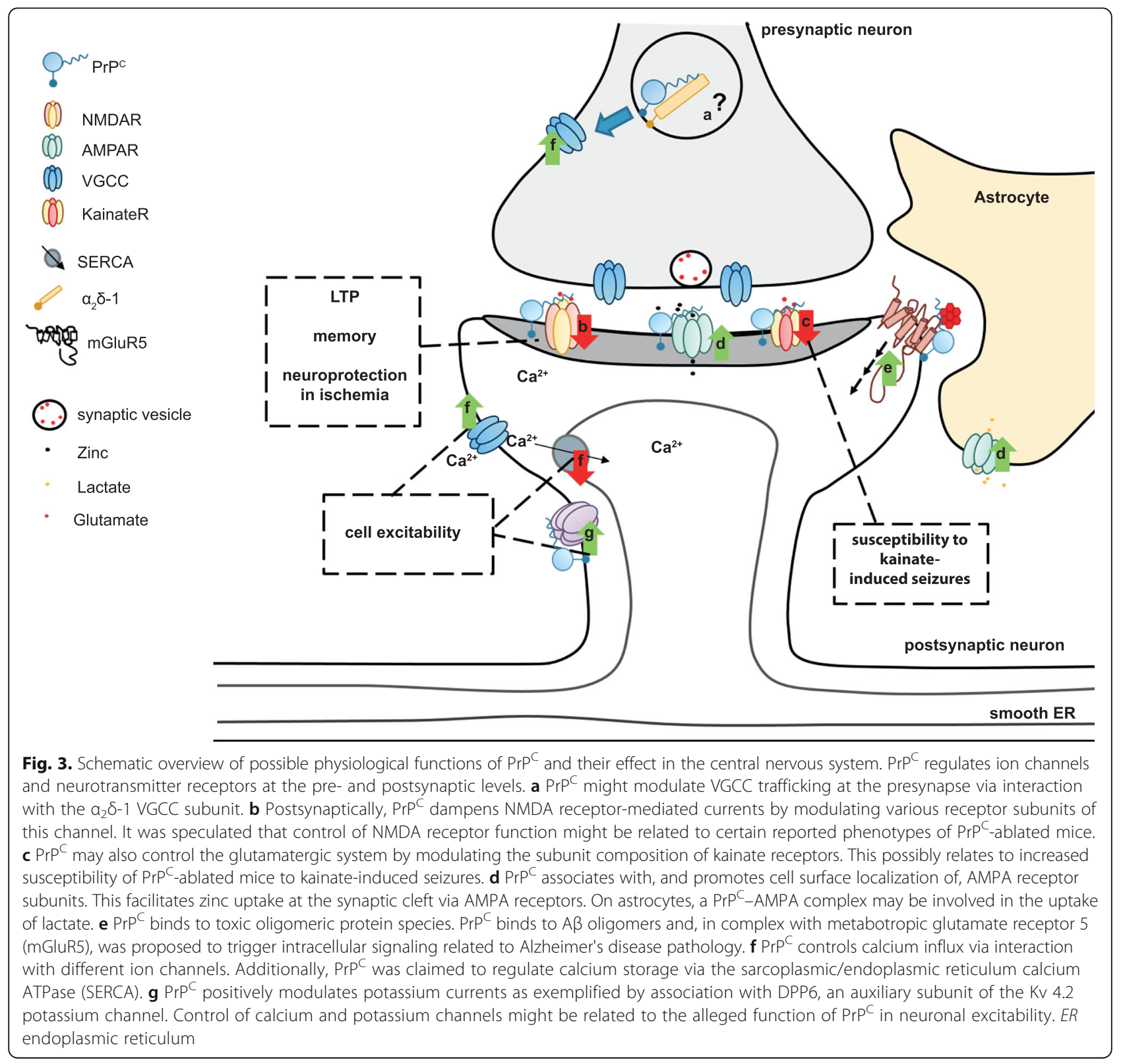


depletion, indicating that this is not a developmental phenotype [39]. At the cellular level, reduced sAHP is expected to result in increased neuronal firing. Increased neuronal excitability in the $\operatorname{PrP}^{\mathrm{C}}$-deficient hippocampus has also been reported in the context of higher vulnerability of $\mathrm{PrP}^{\mathrm{C}}$-deficient mice to kainate-induced seizures (Fig. 3). This was related to the interaction of $\operatorname{PrP}^{\mathrm{C}}$ with the kainate receptor subunit GluR6/7 [84]. Additionally, in the absence of $\operatorname{PrP}^{\mathrm{C}}$, GluR6/7-containing KA receptors were upregulated and the neurotoxic signaling was enhanced [84-86]. This suggests a neuroprotective role of $\operatorname{PrP}^{\mathrm{C}}$ against excitotoxic insults.

However, whether this represents a bona fide $\operatorname{PrP}^{\mathrm{C}}$ phenotype remains controversial. Prnp $^{-1-}$ mice on a different genetic background displayed a reduced susceptibility to kainate-induced seizures in the absence of $\operatorname{PrP}^{\mathrm{C}}$. As this phenotype could not be rescued by reintroduction of an exogenous Prnp gene, it is suspected that polymorphisms in some unidentified Prnp-flanking genes may underlie the discrepant phenotypes [41]. More recently, however, although the effect of the "Prnp-flanking gene" in the KAmediated responses was confirmed in $\operatorname{PrP}^{\mathrm{C}}$-deficient mice of a mixed background (B6129 and B6.129), enhanced sensitivity to epileptogenic drugs was found in the coisogenic Prnp ${ }^{\mathrm{Edbg} / \mathrm{Edbg}}$ mouse [87]. The molecular mechanism underlying this phenotype is unclear but the aa32-93 region of $\operatorname{PrP}^{\mathrm{C}}$ (spanning the octapeptide repeats) and its glycosylphosphoinositol anchor may be involved. Consistent with the higher neuronal excitability of $\operatorname{PrP}^{C_{-}}$deficient mice, anatomical changes within the hippocampus indicated a reorganization of neuronal circuitry similar to the "epileptic neuronal network" seen in certain human epilepsies [88].

$\mathrm{PrP}^{\mathrm{C}}$ might also act as a modulator of glutamate receptors of the NMDA subtype. These are heterotetramers composed of two GluN1 subunits and two GluN2 subunits of different subtypes [89]. It was found that $\operatorname{PrP}^{\mathrm{C}}$ inhibited NMDA receptors and prevented potentially excitotoxic calcium influx through these channels by association with NMDA receptors containing the GluN2D subunit [90], as shown by co-immunoprecipitation and immunofluorescence imaging. Absence of $\operatorname{PrP}^{\mathrm{C}}$ led to upregulation of GluN2D-containing NMDA receptors and enhanced signaling due to prolonged kinetics of NMDAmediated currents [90]. This was subsequently linked to increased depressive-like behavior and increased nociception in $\operatorname{PrP}^{\mathrm{C}}$-deficient mice. Both phenotypes were rescued by pharmacological inhibition of NMDA receptors [91, 92]. Additionally, copper-dependent interaction of $\mathrm{PrP}^{\mathrm{C}}$ with the GluN1 subunit was documented, which was involved in nitrosylation of NMDA subunits GluN2A and GluN1. This represents a second mechanism by which the presence of $\operatorname{PrP}^{C}$ reduces NMDA currents and signaling $[93,94]$.
The putative control of ionotropic glutamate receptors by $\operatorname{PrP}^{\mathrm{C}}$ may be even more complex, since $\operatorname{PrP}^{\mathrm{C}}$ also interacts with $\alpha$-amino-3-hydroxy-5-methyl-4-isoxazolepropionic acid (AMPA) receptor subunits GluA1 and GluA2. This interaction may be relevant to the $\operatorname{PrP}^{C_{-}}$ mediated cellular uptake of zinc through AMPA receptors [95] and to the regulation of lactate transport in astrocytes [96]. Whether the binding of $\operatorname{PrP}^{\mathrm{C}}$ with AMPA receptor subunits also plays a role in AMPA receptor function remains to be elucidated.

\section{$\operatorname{PrP}^{C}$ interactions with metabotropic glutamate receptors and $A \boldsymbol{\beta}$}

Recently, $\operatorname{PrP}^{\mathrm{C}}$ has been shown to interact not only with ionotropic but also with metabotropic glutamate receptors of group I, mGluR1 and mGluR5 (Fig. 2). Metabotropic glutamate receptors are members of the $\mathrm{G}$ protein-coupled receptor (GPCR) superfamily of seven transmembrane-domain proteins that are activated by glutamate and transduce intracellular signals via $\mathrm{G}$ proteins. $\mathrm{PrP}^{\mathrm{C}}$ binds to and signals through mGluR5 in disease-related conditions [97].

Several studies found that $A \beta$ oligomers, the neurotoxic protein species involved in $\mathrm{AD}$, can bind to $\operatorname{PrP}^{\mathrm{C}}$ [98, 99] (Figs. 1 and 2) and activate the Fyn kinase through mGluR5 [97]. A $\beta-\operatorname{PrP}^{\mathrm{C}}-$ mGluR5 complexes are responsible for facilitation of long-term depression (LTD) in vivo [100] and dendritic spine loss in cultured neurons [97]. The $\mathrm{A} \beta-\mathrm{PrP}^{\mathrm{C}}-$ mGlu5R complex might act upstream of the phosphorylation of the NMDA receptor subunit GluN2B. This event within the pathogenic cascade triggered by $\mathrm{A} \beta$ oligomers requires $\operatorname{PrP}^{\mathrm{C}}$-dependent Fyn activation [54] and underlies the $A \beta$ oligomerinduced disruption of LTP in AD.

Focusing on the role of $\operatorname{PrP}^{\mathrm{C}}$, two main considerations can be drawn from these studies. First, $\operatorname{PrP}^{\mathrm{C}}$ appears to function as a cell surface receptor for synaptotoxic oligomers of the $A \beta$ peptide and, as reported by Resenberger and colleagues [101], of other $\beta$-sheet-rich neurotoxic proteins. However, whereas the physical interaction of $\operatorname{PrP}^{C}$ with $A \beta$ oligomers was confirmed $[99,102]$, it is unclear whether $\operatorname{PrP}^{C}$ is necessary for the synaptotoxic effect of A $\beta$ oligomers [102-105]. Secondly, although the interplay between mGluR5 and $\operatorname{PrP}^{C}$ may be relevant to $\mathrm{AD}$ pathology, it remains unclear whether the binding to $\operatorname{PrP}^{\mathrm{C}}$ affects physiological functions of group I metabotropic glutamate receptors. Intriguingly, a role for the $\operatorname{PrP}^{\mathrm{C}}-\mathrm{mGluR} 1$ complex in neurite outgrowth has been reported [106].

\section{Role of $\operatorname{PrP}^{C}$ in development}

During murine embryonic development, $\operatorname{PrP}^{C}$ is expressed as early as a few days post-implantation, suggesting a possible role in development $[107,108]$. Transcriptomic 
analysis of $\operatorname{PrP}^{\mathrm{C}}$ knockout embryos showed several differentially expressed genes (DEGs), while the number of DEGs in brains of adult $\operatorname{PrP}^{\mathrm{C}}$-deficient mice is almost negligible [42, 109]. Interestingly, the number of DEGs is higher in brains where $\operatorname{PrP}^{C}$ had been knocked out postnatally, suggesting that the function of $\operatorname{PrP}^{\mathrm{C}}$ may be compensated for by other proteins during development [110]. To date, only a few in vivo studies on the role of $\operatorname{PrP}^{C}$ in CNS development are available. They suggest that $\operatorname{PrP}^{\mathrm{C}}$-ablated mice exhibit reduced proliferation rates of neuronal progenitor cells in the embryonic, newborn, and adult CNS $[111,112]$. Additionally, increased proliferation of oligodendrocyte precursor cells with a concomitant maturation delay of oligodendrocytes and astrocytes has been reported $[111,113]$. These observations were supported by the results of several in vitro experiments $[111,113,114]$. However, as the genetic background can influence brain development and adult neurogenesis [115], these studies should be confirmed in coisogenic $\operatorname{PrP}^{\mathrm{C}}$-ablated mice.

Additionally, in vitro studies suggest that $\operatorname{PrP}^{C}$ is implicated in the regulation of neuritogenesis $[116,117]$ as well as axonal growth $[48,118,119]$. Also, there is some evidence that $\operatorname{PrP}^{C}$ is involved in the development of the cerebellar circuitry, leading to delayed motor development of $\operatorname{PrP}^{\mathrm{C}}$-deficient mice [120].

\section{Possible neuroprotective roles of $\operatorname{PrP}^{\mathrm{C}}$}

$\operatorname{PrP}^{\mathrm{C}}$ may have a neuroprotective role in a mouse model of cerebral ischemia, as $\operatorname{PrP}^{\mathrm{C}}$-deficient mice show larger lesions in acute cerebral ischemia. Furthermore, overexpression of $\operatorname{PrP}^{\mathrm{C}}$ can reduce the lesion size compared to wild-type mice [121-124]. Attenuation of NMDA signaling by $\operatorname{PrP}^{C}$ has been proposed to be the basis of a neuroprotective role of $\operatorname{PrP}^{\mathrm{C}}$ against NMDA-mediated toxicity in ischemia [125]. Additionally, it was found that cleavage of $\operatorname{PrP}^{\mathrm{C}}$ into its $\mathrm{N}$ - and $\mathrm{C}$-terminal fragments is enhanced under ischemic conditions and these cleavage products can themselves be neuroprotective [124]. In particular, the $\mathrm{N}$-terminal cleavage fragment (N1) might be neuroprotective against staurosporine-induced Caspase-3 activation in a model of pressure-induced ischemia in the rat retina [126]. These results are supported by several in vitro studies, where expression of $\operatorname{PrP}^{\mathrm{C}}$ was protective against staurosporine or anisomycin-induced apoptosis [127, 128]. Conversely, loss of $\operatorname{PrP}^{\mathrm{C}}$ was beneficial against glutamate-induced excitotoxicity in vitro, an effect supposedly mediated by increased uptake of glutamate in $\operatorname{PrP}^{\mathrm{C}}$-ablated astrocytes [129].

The protective function of the $\mathrm{N} 1$ fragment is also very intriguing in the context of the $A \beta$ oligomer-related synaptotoxicity. This intrinsically disordered $\mathrm{N}$-terminal portion of $\operatorname{PrP}^{C}$ is involved in binding to $\beta$-sheet-rich peptides like $A \beta$ oligomers $[99,101]$ and mediates the detrimental effects of $A \beta$ oligomers on synaptic function as mentioned before. However, in its soluble form as secreted upon $\operatorname{PrP}^{\mathrm{C}}$ cleavage, $\mathrm{N} 1$ acted in a decoy receptor-like mode: it prevented $\mathrm{A} \beta$ peptide fibrillization and reduced the neurotoxicity of amyloid- $\beta$ oligomers in vitro and in vivo [130]. Additionally, the rate of $\operatorname{PrP}^{C}$ alpha-cleavage is increased in brain tissue from patients suffering from $A D$ and it was proposed that alphacleavage represents an endogenous protective mechanism against amyloid- $\beta$ toxicity in humans [131].

However, $\operatorname{PrP}^{\mathrm{C}}$-deficient mice do not exhibit altered amyloid- $\beta$ toxicity [102-105] and there was no protective effect of $\operatorname{PrP}^{C}$ in mouse models of other neurodegenerative diseases, including Parkinson's and Huntington's disease, as well as a mouse model of tauopathy $[124,132]$.

Based on in vitro studies, by virtue of its ability to bind copper, $\operatorname{PrP}^{\mathrm{C}}$ has been proposed to participate in resistance to oxidative stress by preventing reactive oxygen species (ROS) generation via free copper-mediated redox reactions. Also, $\operatorname{PrP}^{C}$ was at some point thought to regulate the function of superoxide dismutase (SOD) [133]. It was even proposed that $\operatorname{PrP}^{\mathrm{C}}$ could act as a SOD by itself $[27,134]$. However, a function of $\operatorname{PrP}^{C}$ in copper metabolism is still controversial and the influence of $\operatorname{PrP}^{\mathrm{C}}$ on either SOD level or the intrinsic dismutase activity of $\operatorname{PrP}^{\mathrm{C}}$ was shown by us and others to be artifactual $[135,136]$. There might be, however, alternative ways in which $\operatorname{PrP}^{\mathrm{C}}$ protects against ROS toxicity. For instance, $\operatorname{PrP}^{\mathrm{C}}$ dependent expression of antioxidant enzymes was suggested as an explanation for resistance to oxidative stress mediated by $\operatorname{PrP}^{C}[137,138]$ as well as a conjectured $\operatorname{PrP}^{\mathrm{C}}$ function in iron metabolism and control of redoxiron balance in cell lines $[139,140]$.

\section{Role of $\operatorname{PrP}^{C}$ in the peripheral nervous system}

$\operatorname{PrP}^{\mathrm{C}}$-deficient mice of five different $\operatorname{PrP}^{\mathrm{C}}$-knockout strains, including the $\operatorname{Prnp}{ }^{\mathrm{ZH} 3 / \mathrm{ZH} 3}$ mice (coisogenic to $\mathrm{BL} / 6$ mice), develop a late-onset peripheral neuropathy, indicating that peripheral myelin maintenance is a bona fide physiological function of $\operatorname{PrP}^{C}[42,141,142]$. $\operatorname{PrP} P^{C}$ neuronal expression and amino-proximal cleavage (Fig. 2) are necessary for the promyelinating signal [141]. It was then discovered that the very $\mathrm{N}$-terminal polycationic cluster of $\operatorname{PrP}^{\mathrm{C}}$ binds to the G-protein-coupled receptor Adgrg6 (Gpr126) on Schwann cells (Fig. 1), eliciting a promyelinating cAMP response in vitro and in vivo in mice and zebrafish (Fig. 4) [5]. This pointed to the $\mathrm{N}$-terminal fragment of $\mathrm{PrP}^{\mathrm{C}}$ as a promyelinating factor that might serve as a possible treatment in other peripheral chronic demyelinating polyneuropathies.

In the CNS, Gpr126 is expressed by the Bergmann glia of the developing cerebellum, but not on mature oligodendrocytes, which are responsible for myelination [143]. However, some $\operatorname{PrP}^{C}$ deletion mutants lacking the cleavage site for the $\mathrm{N}$-terminal fragment production 


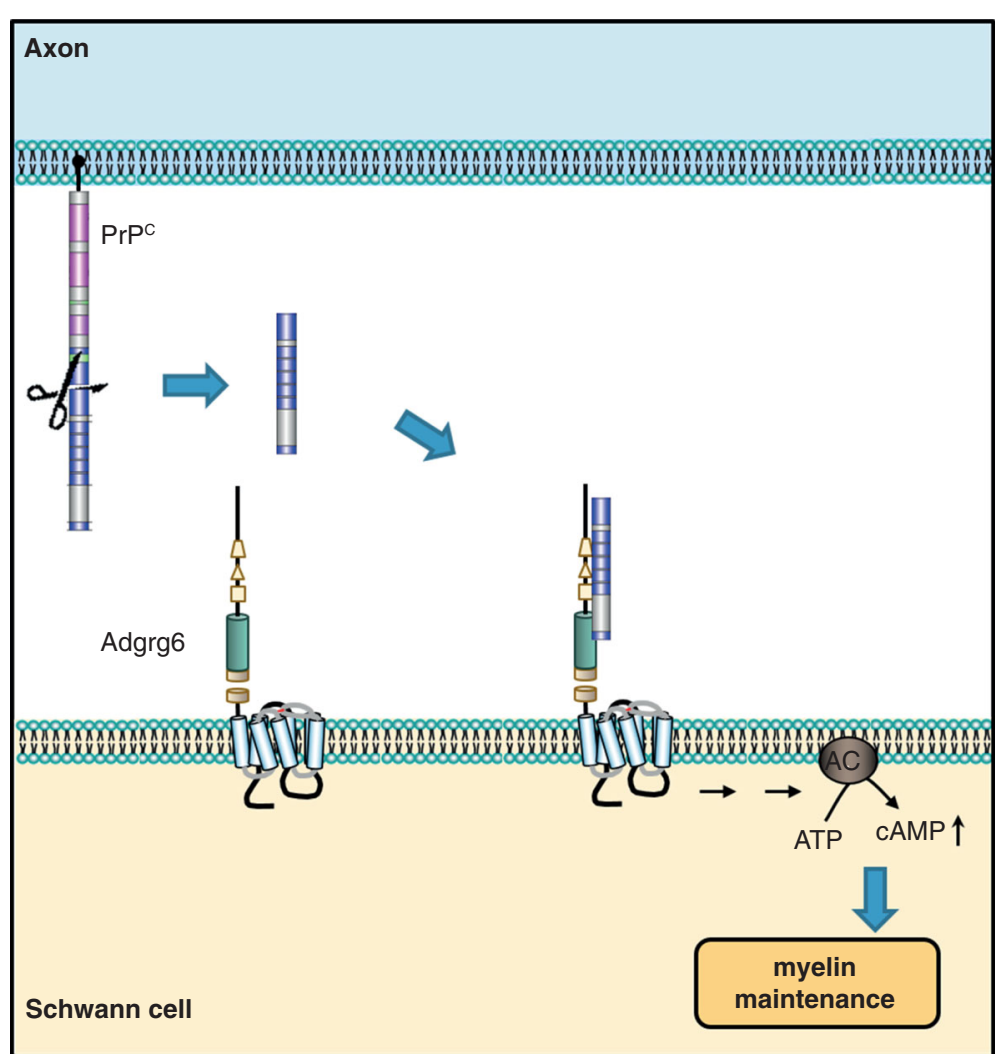

Fig. 4. Axonal $\operatorname{PrP}^{C}$ promotes myelin maintenance in trans via Adgrg6 on Schwann cells. Mice devoid of PrP ${ }^{C}$ develop a chronic demyelinating neuropathy, which suggested a pro-myelinating function of PrPC . In the peripheral nervous system, the N1 fragment of axonal PrPC interacts with Adgrg6 expressed on Schwann cells. This binding elicits activation of Adgrg6, which signals via adenylyl cyclase, thereby leading to increased cellular levels of CAMP. This triggers a well-defined downstream signaling cascade promoting myelin maintenance

also showed severe demyelination in both the spinal cord and cerebellar white matter in vivo [144, 145]. Thus, although in the CNS an eventual $\operatorname{PrP}^{C}$ function in myelin homeostasis is dispensable, a contribution of aberrant $\operatorname{PrP}^{\mathrm{C}}$ function in demyelinating diseases in the brain is a conceivable scenario. Moreover, whether the $\mathrm{N}$-terminal cleavage product of $\operatorname{PrP}^{\mathrm{C}}$ is also signaling via other G-protein-coupled receptors in distinct biological processes is likely, but remains to be elucidated.

\section{PrP ${ }^{C}$ function: the next chapters}

All available data point to $\operatorname{PrP}^{\mathrm{C}}$ exerting its function in concert with additional membrane proteins. On one hand, $\mathrm{PrP}^{\mathrm{C}}$ can regulate the cellular transport and localization of its binding partners. On the other hand, $\operatorname{PrP}^{\mathrm{C}}$ can directly modulate the functionality of the binding partner-as seen for certain ion channels and ionotropic glutamate receptors. Also, $\mathrm{PrP}^{\mathrm{C}}$ can signal in trans via its N-terminal cleavage products. Finally, $\operatorname{PrP}^{\mathrm{C}}$ appears to scavenge amyloid aggregates of $A \beta$, and it will be interesting to see whether further pathological aggregates can also be recognized by $\operatorname{PrP}^{\mathrm{C}}$. Given these findings, the question arises whether the cellular prion protein needs its misfolding-prone structure with a disordered flexible tail to fulfill its physiological function. The fact that the functional domains of $\operatorname{Pr} P^{C}$ are conserved from avians to mammals speaks in favor of this hypothesis [4, 146]. Even though the interpretation of many studies is hampered by the genetic impurity of the mouse models used, there is enough evidence that $\operatorname{PrP}^{\mathrm{C}}$ plays a role in several physiological functions in the central and peripheral nervous systems. Nevertheless, it appears implausible that $\operatorname{PrP}^{\mathrm{C}}$ is involved in such a large number of cellular functions, particularly in view of the small number of validated pathological phenotypes in $\mathrm{PrP}^{\mathrm{C}}$-deficient mice. The emergence of new, rigorously controlled animal models will be of help for revisiting and critically assessing some of these phenotypes.

\section{Acknowledgements}

AA is the recipient of support from an Advanced Grant of the European Research Council (Prion2020), a European Union Framework 7 Grant (NEURINOX), the Swiss National Research Foundation, Sinergia grant \#147660, the Clinical Research Priority Programs "Small RNAs" and "Human Hemato-Lymphatic Diseases", SystemsX.ch and the EU Joint Programme on Neurodegenerative Disease Research (JPND) CureALS and REfrAME. M-AW was supported by an MD/PhD fellowship from the Swiss National Foundation. AS is a recipient of a Forschungskredit of the University of Zurich, grant number [FK - 16 - 048]. 


\section{Authors' contributions}

M-AW, AS, and AA wrote the manuscript. All authors have read the manuscript and agree with its content.

\section{Competing interests}

The authors declare that they have no competing interests.

\section{Publisher's Note}

Springer Nature remains neutral with regard to jurisdictional claims in published maps and institutional affiliations.

\section{Published online: 02 May 2017}

\section{References}

1. Bendheim PE, Brown HR, Rudelli RD, Scala L, Goller NL, Wen GY, et al. Nearly ubiquitous tissue distribution of the scrapie agent precursor protein. Neurology. 1992;42:149.

2. Prusiner SB. Novel proteinaceous infectious particles cause scrapie. Science. 1982;216:136-44. http://dx.doi.org/10.1126/science.6801762.

3. Prusiner SB. Prions. Proc Natl Acad Sci U S A. 1998:95:13363-83.

4. Wopfner F, Weidenhöfer G, Schneider R, von Brunn A, Gilch S, Schwarz TF, et al. Analysis of 27 mammalian and 9 avian PrPs reveals high conservation of flexible regions of the prion protein. J Mol Biol. 1999;289:1163-78.

5. Küffer A, Lakkaraju AKK, Mogha A, Petersen SC, Airich K, Doucerain C, et al. The prion protein is an agonistic ligand of the $\mathrm{G}$ protein-coupled receptor Adgrg6. Nature. 2016;536:464-8.

6. Chesebro B, Race R, Wehrly K, Nishio J, Bloom M, Lechner D, et al. Identification of scrapie prion protein-specific mRNA in scrapie-infected and uninfected brain. Nature. 1985;315:331-3.

7. Oesch B, Westaway D, Wälchli M, McKinley MP, Kent SBH, Aebersold R, et al. A cellular gene encodes scrapie PrP 27-30 protein. Cell. 1985;40:735-46.

8. Westaway D, Cooper C, Turner S, Da Costa M, Carlson GA, Prusiner SB. Structure and polymorphism of the mouse prion protein gene. Proc Natl Acad Sci U S A. 1994;91:6418-22.

9. Riek R, Hornemann S, Wider G, Glockshuber R, Wüthrich K. NMR characterization of the full-length recombinant murine prion protein, mPrP (23-231). FEBS Lett. 1997:413:282-8.

10. Stahl N, Borchelt DR, Hsiao K, Prusiner SB. Scrapie prion protein contains a phosphatidylinositol glycolipid. Cell. 1987;51:229-40.

11. Stahl N, Baldwin M, Hecker R, Pan K-M, Burlingame A, Prusiner S Glycosylinositol phospholipid anchors of the scrapie and cellular prion proteins contain sialic acid. Biochemistry (Mosc). 1992;31:5043-53.

12. Naslavsky N, Stein R, Yanai A, Friedlander G, Taraboulos A. Characterization of detergent-insoluble complexes containing the cellular prion protein and its scrapie isoform. J Biol Chem. 1997;272:6324-31.

13. Morris RJ, Parkyn CJ, Jen A. Traffic of prion protein between different compartments on the neuronal surface, and the propagation of prion disease. FEBS Lett. 2006:580:5565-71.

14. Parizek P. Similar turnover and shedding of the cellular prion protein in primary lymphoid and neuronal cells. J Biol Chem. 2001;276:44627-32.

15. Taylor DR. Assigning functions to distinct regions of the $\mathrm{N}$-terminus of the prion protein that are involved in its copper-stimulated, clathrin-dependent endocytosis. J Cell Sci. 2005;118:5141-53.

16. Peters PJ, Mironov A, Peretz D, van Donselaar E, Leclerc E, Erpel S, et al. Trafficking of prion proteins through a caveolae-mediated endosomal pathway. J Cell Biol. 2003;162:703-17.

17. Harris DA, Huber MT, Van Dijken P, Shyng SL, Chait BT, Wang R. Processing of a cellular prion protein: identification of $\mathrm{N}$-and C-terminal cleavage sites. Biochemistry (Mosc). 1993:32:1009-16.

18. Walmsley AR, Watt NT, Taylor DR, Perera WSS, Hooper NM. a-cleavage of the prion protein occurs in a late compartment of the secretory pathway and is independent of lipid rafts. Mol Cell Neurosci. 2009;40:242-8.

19. Chen SG, Teplow DB, Parchi P, Teller JK, Gambetti P, Autilio-Gambetti L. Truncated forms of the human prion protein in normal brain and in prion diseases. J Biol Chem. 1995;270:19173-80

20. Lewis V, Johanssen VA, Crouch PJ, Klug GM, Hooper NM, Collins SJ. Prion protein "gamma-cleavage": characterizing a novel endoproteolytic processing event. Cell Mol Life Sci. 2016;73:667-83.

21. Westergard L, Turnbaugh JA, Harris DA. A naturally occurring C-terminal fragment of the prion protein (PrP) delays disease and acts as a dominantnegative inhibitor of PrPSC formation. J Biol Chem. 2011;286:44234-42.
22. Yusa S, Oliveira-Martins JB, Sugita-Konishi Y, Kikuchi Y. Cellular prion protein: from physiology to pathology. Viruses. 2012:4:3109-31.

23. Taylor DR, Parkin ET, Cocklin SL, Ault JR, Ashcroft AE, Turner AJ, et al. Role of ADAMs in the ectodomain shedding and conformational conversion of the prion protein. J Biol Chem. 2009;284:22590-600. http://dx.doi.org/10. 1074/jbc.M109.032599.

24. Vincent B, Paitel E, Saftig P, Frobert Y, Hartmann D, De Strooper B, et al. The disintegrins ADAM10 and TACE contribute to the constitutive and phorbol ester-regulated normal cleavage of the cellular prion protein. J Biol Chem. 2001;276:37743-6.

25. Altmeppen HC, Prox J, Puig B, Kluth MA, Bernreuther C, Thurm D, et al. Lack of a-disintegrin-and-metalloproteinase ADAM10 leads to intracellular accumulation and loss of shedding of the cellular prion protein in vivo. Mol Neurodegener. 2011;6:36

26. Altmeppen HC, Prox J, Krasemann S, Puig B, Kruszewski K, Dohler F, et al. The sheddase ADAM10 is a potent modulator of prion disease. Elife. 2015:4, e04260.

27. Brown DR, Clive C, Haswell SJ. Antioxidant activity related to copper binding of native prion protein. J Neurochem. 2001;76:69-76.

28. Büeler HR, Fischer M, Lang Y, Bluethmann H, Lipp HP, DeArmond SJ, et al. Normal development and behaviour of mice lacking the neuronal cell-surface PrP protein. Nature. 1992;356:577-82. http://dx.doi.org/10. 1038/356577a0.

29. Manson JC, Clarke AR, Hooper ML, Aitchison L, McConnell I, Hope J. 129/Ola mice carrying a null mutation in PrP that abolishes mRNA production are developmentally normal. Mol Neurobiol. 1994;8:121-7.

30. Büeler H, Aguzzi A, Sailer A, Greiner R-A, Autenried P, Aguet M, et al. Mice devoid of PrP are resistant to scrapie. Cell. 1993:73:1339-47.

31. Sakaguchi S, Katamine S, Nishida N, Moriuchi R, Shigematsu K, Sugimoto T, et al. Loss of cerebellar Purkinje cells in aged mice homozygous for a disrupted PrP gene. Nature. 1996;380:528-31

32. Katamine S, Nishida N, Sugimoto T, Noda T, Sakaguchi S, Shigematsu K, et al. Impaired motor coordination in mice lacking prion protein. Cell Mol Neurobiol. 1998:18:731-2.

33. Moore RC. Gene targeting studies at the mouse prion protein locus [PhD Thesis]. Edinburgh, Scotland: University of Edinburgh; 1997.

34. Rossi D, Cozzio A, Flechsig E, Klein MA, Rülicke T, Aguzzi A, et al. Onset of ataxia and Purkinje cell loss in PrP null mice inversely correlated with Dpl level in brain. EMBO J. 2001;20:694.

35. Weissmann C, Aguzzi A. PrP's double causes trouble. Science. 1999;286:914.

36. Moore RC, Lee IY, Silverman GL, Harrison PM, Strome R, Heinrich C, et al. Ataxia in prion protein (PrP)-deficient mice is associated with upregulation of the novel PrP-like protein doppel. J Mol Biol. 1999;292:797-817.

37. Lu K, Wang W, Xie Z, Wong B-S, Li R, Petersen RB, et al. Expression and Structural characterization of the recombinant human doppel protein. Biochemistry (Mosc). 2000;39:13575-83.

38. Moore RC, Mastrangelo P, Bouzamondo E, Heinrich C, Legname G, Prusiner SB, et al. Doppel-induced cerebellar degeneration in transgenic mice. Proc Natl Acad Sci U S A. 2001:98:15288-93.

39. Mallucci GR, Ratte S, Asante EA, Linehan J, Gowland I, Jefferys JGR, et al. Post-natal knockout of prion protein alters hippocampal CA1 properties, but does not result in neurodegeneration. EMBO J. 2002;21:202-10.

40. Nuvolone M, Kana V, Hutter G, Sakata D, Mortin-Toth SM, Russo G, et al. SIRP polymorphisms, but not the prion protein, control phagocytosis of apoptotic cells. J Exp Med. 2013:210:2539-52.

41. Striebel JF, Race B, Pathmajeyan M, Rangel A, Chesebro B. Lack of influence of prion protein gene expression on kainate-induced seizures in mice: studies using congenic, coisogenic and transgenic strains. Neuroscience. 2013;238:11-8.

42. Nuvolone M, Hermann M, Sorce S, Russo G, Tiberi C, Schwarz P, et al. Strictly co-isogenic $\mathrm{C} 57 \mathrm{BL} / 6 \mathrm{~J}$ - Prnp $^{-1-}$ mice: A rigorous resource for prion science. J Exp Med. 2016:213:313-27.

43. Richt JA, Kasinathan P, Hamir AN, Castilla J, Sathiyaseelan T, Vargas F, et al. Production of cattle lacking prion protein. Nat Biotechnol. 2007:25:132-8.

44. Yu G. Functional disruption of the prion protein gene in cloned goats. J Gen Virol. 2006:87:1019-27.

45. Benestad SL, Austbø L, Tranulis MA, Espenes A, Olsaker I. Healthy goats naturally devoid of prion protein. Vet Res. 2012:43:87.

46. Minikel EV, Vallabh SM, Lek M, Estrada K, Samocha KE, Sathirapongsasuti JF, et al. Quantifying prion disease penetrance using large population control cohorts. Sci Transl Med. 2016;8:322ra9. 
47. Salès N, Rodolfo K, Hässig R, Faucheux B, Di Giamberardino L, Moya KL. Cellular prion protein localization in rodent and primate brain. Eur J Neurosci. 1998;10:2464-71.

48. Salès N, Hässig R, Rodolfo K, Di Giamberardino L, Traiffort E, Ruat M, et al. Developmental expression of the cellular prion protein in elongating axons. Eur J Neurosci. 2002;15:1163-77.

49. Herms J, Tings T, Gall S, Madlung A, Giese A, Siebert H, et al. Evidence of presynaptic location and function of the prion protein. J Neurosci. 1999;19:8866-75.

50. Mironov A, Latawiec D, Wille H, Bouzamondo-Bernstein E, Legname G, Williamson RA, et al. Cytosolic prion protein in neurons. J Neurosci. 2003;23:7183-93.

51. Borchelt DR, Koliatsos VE, Guarnieri M, Pardo CA, Sisodia SS, Price DL. Rapid anterograde axonal transport of the cellular prion glycoprotein in the peripheral and central nervous systems. J Biol Chem. 1994;269:14711-4.

52. Moya KL, Hässig R, Créminon C, Laffont I, Di Giamberardino L. Enhanced detection and retrograde axonal transport of PrPc in peripheral nerve: cellular prion protein in peripheral nerve. J Neurochem. 2003;88:155-60.

53. Haeberle AM, Ribaut-Barassin C, Bombarde G, Mariani J, Hunsmann G, Grassi J, et al. Synaptic prion protein immuno-reactivity in the rodent cerebellum. Microsc Res Tech. 2000;50:66-75.

54. Um JW, Nygaard HB, Heiss JK, Kostylev MA, Stagi M, Vortmeyer A, et al. Alzheimer amyloid- $\beta$ oligomer bound to postsynaptic prion protein activates Fyn to impair neurons. Nat Neurosci. 2012;15:1227-35.

55. Bate C, Nolan W, McHale-Owen H, Williams A. Sialic acid within the glycosylphosphatidylinositol anchor targets the cellular prion protein to synapses. J Biol Chem. 2016;291:17093-101.

56. Jeffrey M, Halliday WG, Bell J, Johnston AR, MacLeod NK, Ingham C, et al. Synapse loss associated with abnormal PrP precedes neuronal degeneration in the scrapie-infected murine hippocampus. Neuropathol Appl Neurobiol. 2008;26:41-54.

57. Šišková Z, Reynolds RA, O'Connor V, Perry VH. Brain region specific pre-synaptic and post-synaptic degeneration are early components of neuropathology in prion disease. PLoS One. 2013;8:e55004. Mallucc GR, editor.

58. Collinge J, Whittington MA, Sidle KCL, Smith CJ, Palmer MS, Clarke AR, et al. Prion protein is necessary for normal synaptic function. Nature. 1994;370:295-7.

59. Manson J, Hope J, Clarke AR, Johnston A, Black C, MacLeod N. PrP Gene dosage and long term potentiation. Neurodegeneration. 1995;4:113-4.

60. Whittington MA, Sidle KCL, Gowland I, Meads J, Hill AF, Palmer MS, et al. Rescue of neurophysiological phenotype seen in PrP null mice by transgene encoding human prion protein. Nat Genet. 1995;9:197-201.

61. Lledo PM, Tremblay P, DeArmond SJ, Prusiner SB, Nicoll RA. Mice deficient for prion protein exhibit normal neuronal excitability and synaptic transmission in the hippocampus. Proc Natl Acad Sci U S A. 1996;93:2403-7.

62. Carleton A, Tremblay P, Vincent JD, Lledo PM. Dose-dependent, prion protein (PrP)-mediated facilitation of excitatory synaptic transmission in the mouse hippocampus. Pflüg Arch Eur J Physiol. 2001;442:223-9.

63. Bliss TVP, Collingridge GL. A synaptic model of memory: long-term potentiation in the hippocampus. Nature. 1993;361:31-9.

64. Criado JR, Sánchez-Alavez M, Conti B, Giacchino JL, Wills DN, Henriksen SJ, et al. Mice devoid of prion protein have cognitive deficits that are rescued by reconstitution of PrP in neurons. Neurobiol Dis. 2005;19:255-65.

65. Coitinho AS, Roesler R, Martins VR, Brentani RR, Izquierdo I. Cellular prion protein ablation impairs behavior as a function of age. NeuroReport. 2003;14:1375-9.

66. Coitinho AS, Freitas ARO, Lopes MH, Hajj GNM, Roesler R, Walz R, et al. The interaction between prion protein and laminin modulates memory consolidation. Eur J Neurosci. 2006;24:3255-64.

67. Coitinho AS, Lopes MH, Hajj GNM, Rossato Jl, Freitas AR, Castro CC, et al. Short-term memory formation and long-term memory consolidation are enhanced by cellular prion association to stress-inducible protein 1. Neurobiol Dis. 2007;26:282-90

68. Lipp H-P, Stagliar-Bozicevic M, Fischer M, Wolfer DP. A 2-year longitudinal study of swimming navigation in mice devoid of the prion protein: no evidence for neurological anomalies or spatial learning impairments. Behav Brain Res. 1998;95:47-54.

69. Lugaresi E, Medori R, Montagna P, Baruzzi A, Cortelli P, Lugaresi A, et al. Fatal familial insomnia and dysautonomia with selective degeneration of thalamic nuclei. N Engl J Med. 1986;315:997-1003.
70. Mastrianni JA, Nixon R, Layzer R, Telling GC, Han D, DeArmond SJ, et al. Prion protein conformation in a patient with sporadic fatal insomnia. N Engl J Med. 1999;340:1630-8.

71. Tobler I, Gaus SE, Deboer T, Achermann P, Fischer M, Rulicke T, et al. Altered circadian activity rhythms and sleep in mice devoid of prion protein. Nature. 1996;380:639-42.

72. Huber $\mathrm{R}$, Deboer $\mathrm{T}$, Tobler I. Prion protein: a role in sleep regulation? J Sleep Res. 1999;8:30-6.

73. Huber R, Deboer T, Tobler I. Sleep deprivation in prion protein deficient mice and control mice: genotype dependent regional rebound. Neuroreport. 2002;13:1-4.

74. Sánchez-Alavez M, Conti B, Moroncini G, Criado JR. Contributions of neuronal prion protein on sleep recovery and stress response following sleep deprivation. Brain Res. 2007;1158:71-80.

75. Busche MA, Kekuš M, Adelsberger H, Noda T, Förstl H, Nelken I, et al. Rescue of long-range circuit dysfunction in Alzheimer's disease models. Nat Neurosci. 2015;18:1623-30.

76. Tatsuki F, Sunagawa GA, Shi S, Susaki EA, Yukinaga H, Perrin D, et al. Involvement of $\mathrm{Ca} 2+$-dependent hyperpolarization in sleep duration in mammals. Neuron. 2016;90:70-85.

77. Mercer RCC, Ma L, Watts JC, Strome R, Wohlgemuth S, Yang J, et al. The Prion protein modulates A-type K+ currents mediated by Kv4.2 complexes through dipeptidyl aminopeptidase-like protein 6. J Biol Chem. 2013;288:37241-55.

78. Senatore A, Colleoni S, Verderio C, Restelli E, Morini R, Condliffe SB, et al. Mutant PrP suppresses glutamatergic neurotransmission in cerebellar granule neurons by impairing membrane delivery of VGCC a $2 \delta-1$ subunit. Neuron. 2012;74:300-13.

79. Herms JW, Korte S, Gall S, Schneider I, Dunker S, Kretzschmar HA. Altered intracellular calcium homeostasis in cerebellar granule cells of prion protein-deficient mice. J Neurochem. 2000;75:1487-92.

80. Fuhrmann M, Bittner T, Mitteregger G, Haider N, Moosmang S, Kretzschmar H, et al. Loss of the cellular prion protein affects the $\mathrm{Ca} 2+$ homeostasis in hippocampal CA1 neurons. J Neurochem. 2006;98:1876-85.

81. King B, Rizwan AP, Asmara H, Heath NC, Engbers JDT, Dykstra S, et al. IKCa channels are a critical determinant of the slow AHP in CA1 pyramidal neurons. Cell Rep. 2015;11:175-82.

82. Colling SB, Collinge J, Jefferys JGR. Hippocampal slices from prion protein null mice: disrupted $\mathrm{Ca}^{2+}$-activated $\mathrm{K}^{+}$currents. Neurosci Lett. 1996;209:49-52.

83. Powell AD, Toescu EC, Collinge J, Jefferys JGR. Alterations in Ca2 + -buffering in prion-null mice: association with reduced afterhyperpolarizations in CA1 hippocampal neurons. J Neurosci. 2008;28:3877-86.

84. Carulla P, Bribián A, Rangel A, Gavín R, Ferrer I, Caelles C, et al. Neuroprotective role of PrPC against kainate-induced epileptic seizures and cell death depends on the modulation of JNK3 activation by GluR6/7-PSD-95 binding. Mol Biol Cell. 2011;22:3041-54.

85. Maglio LE, Perez MF, Martins VR, Brentani RR, Ramirez OA. Hippocampal synaptic plasticity in mice devoid of cellular prion protein. Mol Brain Res. 2004;131:58-64.

86. Rangel A, Burgaya F, Gavín R, Soriano E, Aguzzi A, del Río JA. Enhanced susceptibility ofPrnp-deficient mice to kainate-induced seizures, neuronal apoptosis, and death: Role of AMPA/kainate receptors. J Neurosci Res. 2007:85:2741-55.

87. Carulla P, Llorens F, Matamoros-Angles A, Aguilar-Calvo P, Espinosa JC, Gavín R, et al. Involvement of PrPC in kainate-induced excitotoxicity in several mouse strains. Sci Rep. 2015;5:11971.

88. Colling SB, Khana M, Collinge J, Jefferys JGR. Mossy fibre reorganization in the hippocampus of prion protein null mice. Brain Res. 1997;755:28-35.

89. Mayer ML. Structural biology of glutamate receptor ion channel complexes. Curr Opin Struct Biol. 2016:41:119-27.

90. Khosravani H, Zhang Y, Tsutsui S, Hameed S, Altier C, Hamid J, et al. Prion protein attenuates excitotoxicity by inhibiting NMDA receptors. Sci Signal. 2008; 181:551.

91. Gadotti VM, Bonfield SP, Zamponi GW. Depressive-like behaviour of mice lacking cellular prion protein. Behav Brain Res. 2012;227:319-23.

92. Gadotti VM, Zamponi GW. Cellular prion protein protects from inflammatory and neuropathic pain. Mol Pain. 2011;7:1.

93. You H, Tsutsui S, Hameed S, Kannanayakal TJ, Chen L, Xia P, et al. A neurotoxicity depends on interactions between copper ions, prion protein, and N-methyl-D-aspartate receptors. Proc Natl Acad Sci U S A. 2012;109:1737-42 
94. Gasperini L, Meneghetti E, Pastore B, Benetti F, Legname G. Prion protein and copper cooperatively protect neurons by modulating NMDA receptor through S-nitrosylation. Antioxid Redox Signal. 2015;22:772-84.

95. Watt NT, Taylor DR, Kerrigan TL, Griffiths HH, Rushworth JV, Whitehouse IJ, et al. Prion protein facilitates uptake of zinc into neuronal cells. Nat Commun 2012;3:1134.

96. Kleene R, Loers G, Langer J, Frobert Y, Buck F, Schachner M. Prion protein regulates glutamate-dependent lactate transport of astrocytes. J Neurosci. 2007;27:12331-40

97. Um JW, Kaufman AC, Kostylev M, Heiss JK, Stagi M, Takahashi H, et al. Metabotropic glutamate receptor 5 is a coreceptor for alzheimer $A \beta$ oligomer bound to cellular prion protein. Neuron. 2013;79:887-902.

98. Laurén J, Gimbel DA, Nygaard HB, Gilbert JW, Strittmatter SM. Cellular prion protein mediates impairment of synaptic plasticity by amyloid- $\beta$ oligomers. Nature. 2009;457:1128-32.

99. Chen S, Yadav SP, Surewicz WK. Interaction between human prion protein and amyloid- $\beta(A \beta)$ oligomers: role of N-terminal residues. J Biol Chem. 2010;285:26377-83.

100. Hu N-W, Nicoll AJ, Zhang D, Mably AJ, O'Malley T, Purro SA, et al. mGlu5 receptors and cellular prion protein mediate amyloid- $\beta$-facilitated synaptic long-term depression in vivo. Nat Commun. 2014;5:3374. http://www.nature. com/doifinder/10.1038/ncomms4374.

101. Resenberger UK, Harmeier A, Woerner AC, Goodman JL, Muller V, Krishnan R, et al. The cellular prion protein mediates neurotoxic signalling of [beta]-sheet-rich conformers independent of prion replication. EMBO J. 2011;30:2057-70.

102. Balducci C, Beeg M, Stravalaci M, Bastone A, Sclip A, Biasini E, et al. Synthetic amyloid- oligomers impair long-term memory independently of cellular prion protein. Proc Natl Acad Sci U S A. 2010;107:2295-300.

103. Calella AM, Farinelli M, Nuvolone M, Mirante O, Moos R, Falsig J, et al. Prion protein and $A \beta$-related synaptic toxicity impairment: Cellular prion protein and amyloid- $\beta$. EMBO Mol Med. 2010;2:306-14

104. Kessels HW, Nguyen LN, Nabavi S, Malinow R. The prion protein as a receptor for amyloid-[bgr]. Nature. 2010;466:E3-4

105. Cisse M, Sanchez PE, Kim DH, Ho K, Yu G-Q, Mucke L. Ablation of cellular prion protein does not ameliorate abnormal neural network activity or cognitive dysfunction in the $\mathrm{J} 20$ line of human amyloid precursor protein transgenic mice. J Neurosci. 2011;31:10427-31.

106. Beraldo FH, Arantes CP, Santos TG, Machado CF, Roffe M, Hajj GN, et al. Metabotropic glutamate receptors transduce signals for neurite outgrowth after binding of the prion protein to laminin $\gamma 1$ chain. FASEB J. 2011;25:265-79.

107. Manson J, West JD, Thomson V, McBride P, Kaufman MH, Hope J. The prion protein gene: a role in mouse embryogenesis? Development. 1992;115:117-22.

108. Tremblay P, Bouzamondo-Bernstein E, Heinrich C, Prusiner SB, DeArmond SJ. Developmental expression of PrP in the post-implantation embryo. Brain Res. 2007;1139:60-7.

109. Benvegnu S, Roncaglia P, Agostini F, Casalone C, Corona C, Gustincich S, et al. Developmental influence of the cellular prion protein on the gene expression profile in mouse hippocampus. Physiol Genomics. 2011;43:711-25.

110. Chadi S, Young R, Le Guillou S, Tilly G, Bitton F, Martin-Magniette M-L, et al. Brain transcriptional stability upon prion protein-encoding gene invalidation in zygotic or adult mouse. BMC Genomics. 2010;11:1.

111. Bribián A, Fontana X, Llorens F, Gavín R, Reina M, García-Verdugo JM, et al. Role of the cellular prion protein in oligodendrocyte precursor cell proliferation and differentiation in the developing and adult mouse CNS. PLoS One. 2012;7, e33872.

112. Steele AD, Emsley JG, Ozdinler PH, Lindquist S, Macklis JD. Prion protein (PrPC) positively regulates neural precursor proliferation during developmental and adult mammalian neurogenesis. Proc Natl Acad Sci U S A. 2006;103:3416-21. http://dx.doi.org/10.1073/pnas.0511290103.

113. Arantes C, Nomizo R, Lopes MH, Hajj GNM, Lima FRS, Martins VR. Prion protein and its ligand stress inducible protein 1 regulate astrocyte development. Glia. 2009:57:1439-49.

114. Prodromidou K, Papastefanaki F, Sklaviadis T, Matsas R. Functional crosstalk between the cellular prion protein and the neural cell adhesion molecule is critical for neuronal differentiation of neural stem/precursor cells: PrP and NCAM in NPC neuronal differentiation. Stem Cells. 2014; 32:1674-87

115. Kempermann G, Gage FH. Genetic influence on phenotypic differentiation in adult hippocampal neurogenesis. Stem Cells Mamm Brain. 2002;134:1-12.
116. Santuccione A, Sytnyk V, Leshchyns'ka I, Schachner M. Prion protein recruits its neuronal receptor NCAM to lipid rafts to activate p59 fyn and to enhance neurite outgrowth. J Cell Biol. 2005;169:341-54.

117. Pantera B, Bini C, Cirri P, Paoli P, Camici G, Manao G, et al. PrP ${ }^{c}$ activation induces neurite outgrowth and differentiation in PC12 cells: role for caveolin-1 in the signal transduction pathway. J Neurochem. 2009;110:194-207.

118. Hajj GNM, Lopes MH, Mercadante AF, Veiga SS, da Silveira RB, Santos TG, et al. Cellular prion protein interaction with vitronectin supports axonal growth and is compensated by integrins. J Cell Sci. 2007;120:1915-26.

119. Kanaani J, Prusiner SB, Diacovo J, Baekkeskov S, Legname G. Recombinant prion protein induces rapid polarization and development of synapses in embryonic rat hippocampal neurons in vitro: Prion protein enhances neuronal polarization. J Neurochem. 2005;95:1373-86.

120. Prestori F, Rossi P, Bearzatto B, Lainé J, Necchi D, Diwakar S, et al. Altered neuron excitability and synaptic plasticity in the cerebellar granular layer of juvenile prion protein knock-out mice with impaired motor control. J Neurosci. 2008;28:7091-103.

121. Shyu W-C. Overexpression of PrPC by adenovirus-mediated gene targeting reduces ischemic injury in a stroke rat model. J Neurosci. 2005;25:8967-77.

122. Weise J, Sandau R, Schwarting S, Crome O, Wrede A, Schulz-Schaeffer W, et al. Deletion of cellular prion protein results in reduced Akt activation, enhanced postischemic caspase-3 activation, and exacerbation of ischemic brain injury. Stroke. 2006;37:1296-300.

123. Doeppner TR, Kaltwasser B, Schlechter J, Jaschke J, Kilic E, Bähr M, et al. Cellular prion protein promotes post-ischemic neuronal survival, angioneurogenesis and enhances neural progenitor cell homing via proteasome inhibition. Cell Death Dis. 2015;6, e2024.

124. Mitteregger G, Vosko M, Krebs B, Xiang W, Kohlmannsperger V, Nölting S, et al. The role of the octarepeat region in neuroprotective function of the cellular prion protein. Brain Pathol. 2007;17:174-83.

125. Black SAG, Stys PK, Zamponi GW, Tsutsui S. Cellular prion protein and NMDA receptor modulation: protecting against excitotoxicity. Front Cell Dev Biol. 2014;2:45. http://journal.frontiersin.org/article/10.3389/ fcell.2014.00045/abstract.

126. Guillot-Sestier MV, Sunyach C, Druon C, Scarzello S, Checler F. The alphasecretase-derived N-terminal product of cellular prion, N1, displays neuroprotective function in vitro and in vivo. J Biol Chem. 2009;284:35973-86. http://dx.doi.org/10.1074/jbc.M109.051086.

127. Chiarini LB, Freitas ARO, Zanata SM, Brentani RR, Martins VR, Linden R. Cellular prion protein transduces neuroprotective signals. EMBO J. 2002;21:3317.

128. Lopes $\mathrm{MH}$. Interaction of cellular prion and stress-inducible protein 1 promotes neuritogenesis and neuroprotection by distinct signaling pathways. J Neurosci. 2005;25:11330-9.

129. Pathmajeyan MS, Patel SA, Carroll JA, Seib T, Striebel JF, Bridges RJ, et al. Increased excitatory amino acid transport into murine prion protein knockout astrocytes cultured in vitro. Glia. 2011;59:1684-94.

130. Fluharty BR, Biasini E, Stravalaci M, Sclip A, Diomede L, Balducci C, et al. An $\mathrm{N}$-terminal fragment of the prion protein binds to amyloid- oligomers and inhibits their neurotoxicity in vivo. J Biol Chem. 2013. http://www.jbc org/cgi/doi/10.1074/jbc.M112.423954.

131. Béland M, Bédard M, Tremblay G, Lavigne $P$, Roucou X. A $\beta$ induces its own prion protein $\mathrm{N}$-terminal fragment (PrPN1)-mediated neutralization in amorphous aggregates. Neurobiol Aging. 2014;35:1537-48.

132. Steele AD, Zhou Z, Jackson WS, Zhu C, Auluck P, Moskowitz MA, et al. Context dependent neuroprotective properties of prion protein (PrP). Prion. 2009;3:240-9.

133. Brown DR, Schulz-Schaeffer WJ, Schmidt B, Kretzschmar HA. Prion proteindeficient cells show altered response to oxidative stress due to decreased SOD-1 activity. Exp Neurol. 1997;146:104-12.

134. Brown DR, Boon-Seng W, Hafiz F, Clive C, Haswell SJ, Jones IM. Normal prion protein has an activity like that of superoxide dismutase. Biochem J. 1999;344:1-5.

135. Waggoner DJ, Drisaldi B, Bartnikas TB, Casareno RLB, Prohaska JR, Gitlin JD, et al. Brain copper content and cuproenzyme activity do not vary with prion protein expression level. J Biol Chem. 2000;275:7455-8.

136. Hutter G, Heppner FL, Aguzzi A. No superoxide dismutase activity of cellular prion protein in vivo. Biol Chem. 2005;384:1279.

137. Klamt F, Dal-Pizzol F, Conte da Frota Jr ML, Walz R, Andrades ME, da Silva $E G$, et al. Imbalance of antioxidant defense in mice lacking cellular prion protein. Free Radic Biol Med. 2001;30:1137-44.

138. White AR, Collins SJ, Maher F, Jobling MF, Stewart LR, Thyer JM, et al. Prion protein-deficient neurons reveal lower glutathione reductase activity 
and increased susceptibility to hydrogen peroxide toxicity. Am J Pathol. 1999;155:1723-30

139. Gasperini L, Meneghetti E, Legname G, Benetti F. In absence of the cellular prion protein, alterations in copper metabolism and copper-dependent oxidase activity affect iron distribution. Front Neurosci. 2016;10:437. http://journal.frontiersin.org/Article/10.3389/fnins.2016.00437/abstract.

140. Singh A, Kong Q, Luo X, Petersen RB, Meyerson H, Singh N. Prion protein (PrP) knock-out mice show altered iron metabolism: a functional role for PrP in iron uptake and transport. PLoS One. 2009;4, e6115.

141. Bremer J, Baumann F, Tiberi C, Wessig C, Fischer H, Schwarz P, et al. Axonal prion protein is required for peripheral myelin maintenance. Nat Neurosci. 2010;13:310-8.

142. Nishida N, Tremblay P, Sugimoto T, Shigematsu K, Shirabe S, Petromilli C, et al. A mouse prion protein transgene rescues mice deficient for the prion protein gene from purkinje cell degeneration and demyelination. Lab Invest. 1999;79:689-97.

143. Koirala S, Corfas G. Identification of novel glial genes by single-cell transcriptional profiling of bergmann glial cells from mouse cerebellum. PLoS One. 2010;5, e9198.

144. Radovanovic I. Truncated prion protein and Doppel are myelinotoxic in the absence of oligodendrocytic PrPC. J Neurosci. 2005;25:4879-88.

145. Baumann F, Tolnay M, Brabeck C, Pahnke J, Kloz U, Niemann HH, et al. Lethal recessive myelin toxicity of prion protein lacking its central domain. EMBO J. 2007;26:538-47.

146. Rivera-Milla E, Oidtmann B, Panagiotidis CH, Baier M, Sklaviadis T, Hoffmann R, et al. Disparate evolution of prion protein domains and the distinct origin of Doppel- and prion-related loci revealed by fish-to-mammal comparisons. Faseb J. 2006;20:317-9.

147. Herms JW, Kretzschmar HA, Titz S, Keller BU. Patch-clamp analysis of synaptic transmission to cerebellar Purkinje cells of prion protein knockout mice. Eur J Neurosci. 1995;7:2508-12.

148. Nishida N, Katamine S, Shigematsu K, Nakatani A, Sakamoto N, Hasegawa S, et al. Prion protein is necessary for latent learning and long-term memory retention. Cell Mol Neurobiol. 1997;17:537-45. 